\title{
Diversity Assessment and Cultivar Identification in Date Palm through Molecular Markers- A Review
}

\author{
Nadia Faqir ${ }^{*}$, Aish Muhammad², Muhammad Zeeshan Hyder ${ }^{3}$ \\ ${ }^{I}$ Department of Plant Genomics and Biotechnology, PARC Institute of Advanced Studies in Agriculture (PIASA), National Agriculture \\ Research Center (NARC), Islamabad, Pakistan \\ ${ }^{2}$ National Institute for Genomics and Advanced Biotechnology (NIGAB), National Agricultural Research Center, Islamabad, 45550, \\ Pakistan \\ ${ }^{3}$ Department of Biosciences, COMSATS Institute of Information Technology (CIIT) Islamabad, Pakistan
}

\begin{tabular}{l}
\hline A R T I C L E I N F O \\
Review Article \\
Received 14 May 2017 \\
Accepted 09 November 2017 \\
\hline
\end{tabular}

Keywords:

Phoenix dactylifera

DNA markers

Single Nucleotide Polymorphism

Microsatellite Simple Sequence

Repeat markers

Diversity assessment

$\frac{{ }^{*} \text { Corresponding Author: }}{\text { E-mail: nadiafaqirmuhammad@gmail.com }}$

\begin{abstract}
A B S T R A C T
Date palm has a long history of cultivation and a valuable germplasm with little knowledge about its genetic makeup and variation among the most cultivated cultivars. Diversity is the variability of a species. Plants show variation in yield, vegetative traits and morphological properties of fruits and seeds in response to environmental changes. Molecular markers or DNA markers have been in use since past three decades. The DNA profiles give information about the genotype, screen the whole genome and show variation in both the coding and noncoding region and hence give information about polymorphism. Since plastid genes are transferred mostly from the mother line, the identification of maternal lines is possible by the sequencing of plastid genes. Simple sequence repeats (SSRs) can detect length variation with the help of Polymerase Chain Reaction (PCR) and may be used as highly informative genetic markers. Single Nucleotide Polymorphism (SNPs) are the third generation of molecular markers. SNPs are more stable and have high fidelity of inheritance as compared to other marker systems. Molecular markers have been developed but they are not enough for sufficient diversity assessment. Therefore there is a need to increase the number of DNA markers in date palm. Previously, there are several studies to type various commercially important germplasm based on morphological or yield parameters. Morphological and biochemical markers are limited in number and are affected by environmental factors and growth stage of the plant which reduce their reliability in the assessment of diversity and characterization of the germplasm. This necessitates the use of genetic characterization, utilizing DNA markers, gene sequencing or SNP genotyping which can work independent of the plant growth stage and are not affected by environmental factors. A combination of morphological, biochemical and molecular characterization of the date palm cultivars can better assess the level of diversity and relationship among the cultivars.
\end{abstract}

\section{Introduction}

Date palm is a monocotyledonous and dioecious plant. Date palm culture is important for its nutritive, economic and social value in the arid and semiarid environments of the world. Being out crossing in nature the tree presents huge diversity in cultivars with separate male and female plants. Female trees are mainly important for their nutritious fruits. Date palm has been cultivated since 5000 years and there exist almost 3000 varieties of date palm in the world (Jain et al., 2011).

Diversity is the variability of a species. Plants show variation in yield, vegetative traits and morphological properties of fruits and seeds in response to environmental changes (Jahromi et al., 2007; Odewale et al., 2012). Diversity in a population, breeding line or germplasm accessions can be analysed on the basis of pedigree data, agronomic traits, morphological attributes, biochemical data and DNA based molecular data. Assessment of genetic diversity is important for genetic variability analysis of the cultivars, identification of the parental combination which may provide maximum diversity for selection, introduction of the desirable genes from diverse origin into the existing germplasm and in the identification of varieties for their protection (Muhammadi and Parasana, 2003). Genetic diversity measurements can be used for increasing genetic variability in populations that have high level of genetic distance as well as to introduce the foreign germplasm (Elmeer et al., 2011). 
Genetic diversity in date palm may be the result of dissemination of the germplasm with human migration, human selection and clonal propagation (Chaludvadi et al., 2014). Commercial cultivars of date palm have been disseminated by offshoots from oasis situated in the center of origin and diversity of date palm in lower Mesopotamia and eastern Arabia. Cultivars propagated by offshoots are almost similar, whereas the less important and non-commercial cultivars are a result of seed dissemination. Adapted cultivars are a result of natural and human selection. Human selection is based mainly on fruit traits and resistance to biotic and abiotic stresses. While non-commercial cultivars propagated through seeds have also gone through natural selection (Jaradat, 2011). Human selection of cultivars is made on the basis of fruit traits and resistance to biotic and abiotic stresses. Whereas non-commercial cultivars which disseminate through seed go through natural selection only (Jaradat, 2011).

There was no model descriptor for date palm until 2006, when Rizk and Sharabsy proposed a set of descriptors for date palm. The descriptors included parameters of passport data, ecogeographical data, management and characterization data and ethnobotanical data. Management and characterization data included vegetative, fruit and seed parameters, inflorescence traits, molecular markers, biochemical and cytological parameters (Rizk and Sharabasy, 2006).

Phenotypic markers of date palm such as leaves, leaflets and spines (Elhoumaizi et al., 2002), offshoots and inflorescence along with isozyme markers (Azequor et al., 2002; Salem et al., 2008; Hammadi et al., 2009), fruit morphological traits (Markhand et al., 2010), inflorescence, fruit and leaf along with molecular markers (Hammadi et al., 2011; Al-Khalifah et al., 2012; Haider et al., 2015), and seeds (Naqvi et al., 2015) have been used for the characterization of date palm germplasm. Similarly, Rivera et al. (2008) studied 45 qualitative and 37 quantitative characters of date palm in the Western Europe and Eissa et al. (2009) studied 77 morphological traits for differentiation among soft date palm varieties of Egypt, but these markers were not sufficient to distinguish among the closely related cultivars before fruiting. For clear demarcation among the closely related cultivars, a large number of phenotypic characters need to be scored in plants which is very laborious and time consuming. Moreover, the plant needs to be grown up to its reproductive stage so that inflorescence, fruit and seeds should be scored which in case of date palm takes 5 to 8 years (Al-Dous et al., 2011). Morphological markers have certain limitations. Firstly, the variation among the studied plants is not sufficient, secondly there may be biasness in the data collection and treatment of plants and thirdly these markers are prone to the variations caused by the environment (Nybom et al., 2014).

This article reviews the utilization of molecular markers for analysis of genetic diversity and development of an identification system for date palm cultivars based on molecular markers.

\section{Molecular markers}

Molecular markers are genetic loci that can be easily traced and measured in a population and may be associated with a particular gene or trait of interest. Molecular markers or DNA markers have been in use since past three decades. The first reported use of DNA polymorphism detection was the construction of a genetic map through Restriction Fragment Length Polymorphism (Botstien et al., 1980). DNA markers are preferred over biochemical markers due to their high quality and high information content. The DNA profiles give information about the genotype. They screen the whole genome and show variation in both the coding and noncoding region and hence give information about polymorphism (Jehan and Lakhanpaul, 2006).

Techniques used for the detection of molecular markers are Amplified Fragment Length Polymorphism (AFLP), Rapid Amplified Polymorphic DNA (RAPD), Restriction Fragment Length Polymorphism (RFLP), Simple Sequence Repeat (SSR) markers and Inter Simple Sequence Repeat markers (ISSR). DNA markers provide information on the similarity or diversity of various clones and varieties which can be hardly differentiated on morphological basis. These markers have been used in date palm for the assessment of similarity or diversity of various clones and varieties that are difficult to differentiate on the basis of molecular traits AFLP and RAPD being the first generation of molecular markers have been used alone or in combination with other markers for diversity assessment in date palm cultivars (Cao and Chao, 2002; Diaz, 2003; Adawy et al., 2005; Jubrael et al., 2005; Al Essar et al., 2005; El Houmaizi et al., 2006; Saker et al., 2006; Soumaya et al., 2011). RAPD markers have also been used in date palm by AlKhalifa et al. (2006), Rawashdeh and Amri (2006), Rani et al. (2007), Al Khalifa et al. (2012), Mirbahar et al. (2014) and Yousaf et al. (2015). ISSRs were used by Hammadi et al. (2012) and Ahmad and AlHadidi (2014), RAPD and ISSR by Abdullah and Gamal (2010) and Marsafari and Mehrab (2013).

\section{Utilization of chloroplast DNA in diversity analysis}

The sequences of genes or fragments of chloroplast DNA in plants have been used successfully for fingerprinting to study diversity and to identify the species. Chloroplast DNA being smaller than nuclear and mitochondrial genome and highly conserved due to slow nucleotide substitution rate is useful for phylogenetic studies (Zurawski and Clegg, 1987). Ribulose biphosphate carboxylase larger subunit has more variable sites than nuclear 18S rDNA to be used in phylogenetic studies (Nickrent and Sotis, 1995). Unlike animals where only one gene encoding cytochrome oxidase 1 (CO1) is enough for phylogenetic studies, plants lack such a universal barcode. Phylogeny of Palms can be reliably estimated by the use of data of chloroplast genes like rbcL (ribulose biphosphate carboxylase larger subunit) and atpB (Hahn, 2002). Consortium for Barcode of Life 
(CBOL) plant working group has suggested two locus barcode for plants comprising of matK $+\mathrm{rbcL}$ (maturase $\mathrm{K}+$ Ribulose biphosphate carboxylase larger subunit) on the basis of their sequence quality, recoverability and power of discrimination among the species. Ribulose biphosphase carboxylase larger subunit (rbcL) is a chloroplast gene of $1400 \mathrm{bp}$ in length encoding ribulose 1 , 5 biphosphate carboxylase oxygenase. matK encodes maturase needed for photosynthetic like activities of the chloroplast. It is a $1500 \mathrm{bp}$ gene located within the trnk intron (Barthet and Hilu, 2007). The resolution power of matK is better than other regions like rpoC, trnH-psbA, rbcL and atpF-atpH (Burgess et al., 2011). Overall the informativeness of matK was found to be 2.6 times greater than that of atpB and rcbL (Hilu et al., 2014). Chloroplast DNA sequence of rpoB and psbA-trnH can be used as molecular signature in date palm at seedling stage as there are 173 variable sites in the combined matrix of 1147 characters (Al-Qurainy et al., 2011). matK alone or in combination with other genes has the potential to distinguish among the date palm cultivars (Enan and Ahmad, 2014). Rps14 gene when used for the assessment of diversity in date palm cultivars from Pakistan showed very little genetic distance (0.001), low average evolutionary divergence (0.008) and low (0.007) nucleotide diversity (Akhtar et al., 2014).

\section{Microsatellite DNA markers}

Simple Sequence Repeats (SSRs) are segments of repeated DNA sequence in higher eukaryotic genome. They can detect length variation with the help of Polymerase Chain Reaction (PCR) and may be used as highly informative genetic markers (Powell et al., 1996). SSR markers are popular for the analysis of plant diversity because these are PCR based co-dominant markers which show high allelic diversity at different loci (Elmeer et al., 2011). Simple sequence repeats are abundantly present in the higher eukaryotic genomes and are highly polymorphic than other genetic markers. These are helpful in the identification of cultivars, analysis of pedigree, germplasm characterization and genetic mapping studies (Billote et al., 2004).

\section{Date palm diversity evaluation based on simple sequence repeat (SSR) markers}

The first SSR markers published for date palm were constructed by Billotte et al. (2004). This microsatellite library was rich in (GA)n repeats and characterized 16 SSR loci in date palm (Table 1).

These markers have been widely used by many researchers across the date palm growing countries for the assessment of diversity and identification of the cultivars. Three loci i.e. mpdCIRO78, mpdCIRO85 and mpdCIRO25 were found to be polymorphic among 49 accessions of date palm cultivars from Tunisia (Zehdi et al., 2004), while on the other hand, these markers were unable to confirm the genetic identity and true to typeness of 60 date palm accessions from Sudan (Elshibli and Korpelainen, 2008), 45 cultivars from Pakistan (Faqir et al., 2016), and 12 cultivars from Qatar (Elmeer and Mattat, 2015). Ten SSR primers (mPdCIR010, mPdCIR016, mPdCIR025, mPdCIR032, mPdCIR035, mPdCIR044, mPdCIR070, mPdCIR085, mPdCIR090 and $m P d C I R 093)$ resulted in unique fingerprints for the important genotypes of date palm from Oman (AlRuqaishi et al., 2008). These markers were used successfully for the genetic diversity analysis of date palm cultivars from Qatar (Ahmad and Al-Qaradawi, 2009). When used in combination with morphological and chemical markers, these microsatellite loci proved to be helpful in grouping of the cultivars (Elshibli and Korpelainen, 2009 and 2010, Hammadi et al., 2011; Bodianet al., 2012).

Akkak et al. (2009) isolated and screened forty one microsatellite loci from two libraries of Phoenix dactylifera L. They used a set of thirty one date palm cultivars for characterization and evaluation of seventeen screened markers. High polymorphism was measured in the studied samples. Most of these markers were also found to be helpful in phylogenetic studies of other species of phoenix.

Table 1 List of SSR markers used frequently for the detection of genetic variation in date palm

\begin{tabular}{l|llll}
\hline Primer & Forward sequence & Reverse Sequence & RM & EAS \\
\hline mPdCIR010 & ACCCCGGACGTGAGGTG & CGTCGATCTCCTCCTTTGTCTC & $(G A)_{22}$ & $114-236$ \\
mPdCIR015 & AGCTGGCTCCTCCCTTCTTA & GCTCGGTTGGACTTGTTCT & $(G A)_{15}$ & $104-150$ \\
mPdCIR016 & AGCGGGAAATGAAAAGGTAT & ATGAAAACGTGCCAAATGTC & $(G A)_{14}$ & $104-198$ \\
mPdCIR025 & GCACGAGAAGGCTTATAGT & CCCCTCATTAGGATTCTAC & $(G A)_{22}$ & $192-244$ \\
mPdCIR032 & CAAATCTTTGCCGTGAG & GGTGTGGAGTAATCATGTAGTAG & $(G A)_{19}$ & $248-310$ \\
mPdCIR035 & ACAAACGGCGATGGGATTAC & CCGCAGCTCACCTCTTCTAT & $(G A)_{15}$ & $154-198$ \\
mPdCIR044 & ATGCGGACTACACTATTCTAC & GGTGATTGACTTTCTTTGAG & $(\text { GA })_{19}$ & $250-330$ \\
mPdCIR048 & CGAGACCTACCTTCAACAAA & CCACCAACCAAATCAAACAC & $(G A)_{32}$ & $108-198$ \\
mPdCIR050 & CTGCCATTTCTTCTGAC & CACCATGCACAAAAATG & $(G A)_{21}$ & $114-208$ \\
mPdCIR057 & AAGCAGCAGCCCTTCCGTAG & GTTCTCACTCGCCCAAAAATAC & $(\text { GA })_{20}$ & $214-284$ \\
mPdCIR063 & CTTTTATGTGGTCTGAGAGA & TCTCTGATCTTGGGTTCTGT & $(G A)_{17}$ & $100-216$ \\
mPdCIR070 & CAAGACCCAAGGCTAAC & GGAGGTGGCTTTGTAGTAT & $(G A)_{17}$ & $154-230$ \\
mPdCIR078 & TGGATTTCCATTGTGAG & CCCGAAGAGACGCTATT & $(G A)_{13}$ & $106-184$ \\
mPdCIR085 & GAGAGAGGGTGGTGTTATT & TTCATCCAGAACCACAGTA & $(G A)_{29}$ & $110-201$ \\
mPdCIR090 & GCAGTCAGTCCCTCATA & TGCTTGTAGCCCTTCAG & $(G A)_{26}$ & $108-202$ \\
mdCIR093 & CCATTTATCATTCCCTCTCTTG & CTTGGTAGCTGCGTTTCTTG & $(\text { GA })_{16}$ & $150-188$ \\
\hline
\end{tabular}

RM: Repeat motif, EAS: Expected Allele size(bp) 
Hamweih et al. (2010) developed 1000 microsatellite markers through the date palm genome. They found dinucleotide repeats to be the most frequent (52442 motifs) type of microsatellite repeats with GA being the most common dinucleotide $(48.7 \%)$ among them. They suggested their use in genetic study and diversity analysis of date palm. These markers when used assessed the genetic diversity of eleven date palm cultivars selected from different areas of Qatar (Elmeer et al. 2011), 45 cultivars from Pakistan (Faqir et al., 2016) and 30 cultivars from Iran (Khierallah et al. 2011) grouped the studied cultivars but identification of individual cultivar was still not possible. SSR markers are important for evaluation of taxonomy up to species level but sequence based phylogenetic analysis is needed to detect the sufficient level of variation (Pintaud et al., 2010). They suggested that these markers can be used in genetic study and diversity analysis of date palm crop. These markers have been used for the assessment of genetic diversity of date palm cultivars in Qatar (Elmeer et al., 2011), Pakistan (Faqir et al., 2016) and Iran (Khierallah et al., 2011). In all these studies SSR markers grouped the studied cultivars into different clusters but the identification of individual cultivars was still not possible. SSR markers are important for evaluation of a crop up to species level but for detection of variation at individual level, phylogenetic analysis based on sequencing data is needed (Pintaud et al., 2010).

Arabnehzad et al. (2012) constructed two SSR enriched libraries comprising of (AG)n and (AAG)n repeat motifs and designed 25 primer pairs, 22 of which were able to differentiate among 16 date palm cultivars from Iran, Iraq and Africa. Cluster analysis successfully differentiated the African cultivars from Iraqi and Iranian date palms. Although an identification key has been developed for 101 accessions of date palm by Zehdi et al. (2012) using only five loci but those loci were not able to differentiate 45 cultivars grown in Pakistan (Faqir et al., 2016). Raachi et al. (2014) genotyped 18 date palm cultivars from Libya using 16 SSR loci. The resulting 110 alleles showed a high polymorphism among the cultivars. They also developed a varietal identification key with the help of only three SSR loci identifying 23 alleles. Yusuf et al. (2015) used six SSR markers for investigating the diversity among 14 Nigerian and Saudi date palm cultivars. They were able to characterize the 14 cultivars with only two markers mpdCIR025 and mpdCIR050. They did not find any gender specific allele with SSR markers but the polymorphism detected among the studied cultivars was high $(83.3 \%)$.

Zhao et al. (2012) analysed EST sequences of date palm genome data base and identified 4,609 ESTs containing simple sequence repeats. They found that trinucleotide motifs were the most common (69.75\%). The percentages of dinucleotide and tetra nucleotides were $9.6 \%$ and $10.4 \%$ respectively. They designed 4,697 primer pairs for EST-SSR markers from computational data. Twenty of primer pairs were randomly selected from the designed primers to check the polymorphism of twelve date palm cultivars. Thus showing that date palm EST sequences exhibit a good resource for developing gene based markers to be used for diversity study. They showed that gene based SSR markers can be developed from EST sequences for use in diversity study. Faqir et al. (2016) analysed genetic diversity among forty five date palm cultivars grown in Pakistan using forty six SSR primers developed by Billotte et al. (2004) and Akkak et al. (2009). Only two primers mpdCIRO25 and mpdCIR085 amplified polymorphic bands thus showing greater similarity in morphologically diverse cultivars of date palm. Maryam et al. (2016) used 12 SSR primers to assess 30 date palm samples including 8 males and 6 females. These primers also classified the studied date palm samples into male and female plants. Thus SSR markers used in this study were also found to be useful in sex discrimination of the date palm. Their study thus suggests the utility of SSR markers for sex determination in date palm cultivars. AlFaifi et al. (2016) developed 93 microsatellite markers and detected high genetic diversity among 32 date palm cultivars by the use of these markers. Al-Najm et al. (2017) used SSR markers developed by Billotte et al. (2004) and Akkak et al. (2009) for analysis of molecular diversity and population structure of 60 date palm cultivars grown in Australia. They found that Australian germplasm has huge diversity providing basis for date palm improvement, increase in production and conservation of genetic resources. Zhao et al. (2017) characterized 911 gene based SSRs for EST sequences in date palm that will provide foundation for development in diversity studies, QTL mapping and molecular breeding. Variation in these SSR markers will help in the development of markers associated with biochemical or physiological functions. Filho et al. (2017) has identified 1555726 microsatellites in date palm and oil palm that brings opportunity for development of molecular markers to be applied in breeding programs for selection of superior genotypes. Torres et al. (2017) reviewed the usefulness of 225 SSR markers for diversity study among the date palm cultivars and recommended a small subset of 19 SSR markers to be useful for further analysis.

\section{Date palm diversity evaluation based on RAPD, AFLP and ISSR markers}

RAPD markers are the first generation of molecular markers and have been used alone or in combination with other molecular markers for diversity analysis and cultivar identification in date palm (Al-Khalifa, 2006; Ibrahim and Amri, 2006; Rani et al., 2007; Marsafari and Mehrab, 2013; Mirbahar et al., 2014; Ahmad and AlHadidi, 2014; Yusuf et al., 2015). Eissa et al. (2016) studied polymorphism among 9 date palm cultivars from Egypt using seventy seven morphological attributes, 9 RAPD-PCR markers and four ISSR markers and concluded that molecular markers have more discriminating powers among the varieties than morphological attributes. Yazal et al. (2017) used RAPD markers for identification and selection of male pollinators in date palm. Their study provide useful procedure for identification of date palm cultivars for effective use of male date palm for pollination. Their use is very simple and cost effective but being dominant in nature and less reproducible reduce their reliability (Semagn et al., 2006). Although the use of RAPD markers is very simple and economical but these markers are dominant in nature and their results are less reproducible therefore these are less reliable (Semagn et al., 2006). 
The AFLP markers have efficiently identified the studied date palm cultivars (Cao and Chao, 2002; Diaz et al., 2003). AFLP is more effective in detecting high level of polymorphism (Sami et al., 2005). Jubrael et al. (2005) used four AFLP markers namely P101(accg/M95(aaaa), P74(ggt)/M95(aaa), P73(ggg/M95(aaa) and P100(aacc)/M95(aaa) and suggested that any combination of these four markers can successfully identify all the varieties. El Houmaizi et al. (2006) confirmed Medjool as a landrace variety of date palm in Morocco through genetic analysis using AFLP markers. Saker et al. (2006) assessed the genetic variation in tissue culture derived date palm offshoots using RAPD and AFLP methods. The genetic stability of the tissue culture derived dry date palm cultivars was confirmed by low genetic variation. Kheriallah et al. (2011) used AFLP for evaluation of genetic diversity among 18 date palm varieties from Iraq. They obtained 83 polymorphic AFLP fragments by the use of six primer combinations with an average of 13.8 polymorphic bands per primer pair. All the primer pairs helped in differentiation of date palm varieties showing the efficiency of AFLP technique for the assessment of genetic diversity in date palm. Their results also showed large genetic diversity among the studied date palm cultivars. Abdullah and Gamal (2010) applied three types of markers such as protein RAPDPCR and ISSR on four important cultivars in Saudi Arabia i.e Med 3002b1, Sugaylb1, Halasb1 and Sukkari b. Inter varietal variation was investigated using five RAPD and five ISSR markers were also applied to assess the genetic polymorphism. Most of the cultivars had the narrow genetic diversity as already expected. The result of the analysis can be used for the selection of the possible parents to generate mapping population. AFLP proved to be more informative than the RAMPO method due to the greater number of markers per assay in AFLP with 0.7 PIC value and 50.54 marker index (Soumaya et al., 2011). Inter varietal variation of these cultivars was also investigated using five RAPD and five ISSR markers. The studied cultivars had a narrow genetic diversity. This knowledge can help in the selection of parents for producing mapping population for further studies. AFLP markers are more informative than the RAMPO (Random Amplification Microsatellite Polymorphism) markers because AFLP markers can assess greater number of loci per assay as compared to RAMPO (Soumaya et al., 2011).

AFLP markers have some merits over other marker. Firstly there is no need of genome sequence information. Secondly their results are reproducible and are thus reliable and thirdly these markers can analyse many polymorphic loci at once (Powel et al., 1996) there are certain demerits of AFLP markers like high cost of chemical (enzymes, ligators, adaptors, polyacrylamide gel and silver nitrate) use in their analysis and their dominant nature which make them unable to differentiate between homozygous and heterozygous individuals.

Ahmad and AlHadidi (2014) used eighteen ISSR markers for the evaluation of genetic diversity and relationship among fifteen cultivars from Qatar. They found that although the cultivars were different in their agronomic traits genetically they were interrelated. Hammadi et al. (2012) found that fruit consistency which is an important characteristic of date fruit has association with genetic markers because clustering based on fruit consistency is in accordance with clustering by microsatellite markers.

\section{Date palm diversity evaluation based on single nucleotide polymorphism (SNPs)}

SNPs are the third generation of molecular markers. SNPs are selected as markers when enough sequence information about the organism being investigated and the tools for the analysis of generated data is available (Bagali et al., 2010). SNPs are more stable and have high conformity of inheritance as compared to other marker systems (Gupta et al., 2001). SNP is the type of polymorphism that occur among DNA samples with respect to single base. These are single base pair positions in the genome where different alleles exists in normal individual of a population. In DNA molecule theoretically four possible nucleotides are involved, but actually only two of these four possibilities have been observed at a particular site in a population. Thus SNPs are largely biallelic, thus making them less informative but their abundance in the genomes overcomes this deficiency as more number of loci can be examined for polymorphism. Limited data is available on SNPs in plants because SNPs development requires huge cost. SNPs in the coding sequence may result in the morphological polymorphism or an association with some trait. Similarly SNPs present near the coding region can also be used in marker assisted selection (Jehan and Lankhanpaul, 2006). SNP markers are the best for characterizing and conserving the gene bank material while for analysis of diversity and fingerprinting AFLP and SSR are suitable (Varshney et al., 2005).

Date palm has a typical chloroplast genome with little rearrangement and gene loss or gain. High-throughput sequencing technology facilitates the identification of intravarietal variations in chloroplast genomes among different cultivars. The date palm chloroplast genome is $158,462 \mathrm{bp}$ in length. Seventy eight SNPs as major intravarietal polymorphisms were identified by Yang et al. (2010) after extracting 369,022 cp sequencing reads from their whole-genome-shotgun data by putting together an assembly and validating it with intensive PCR-based verification, coupled with PCR product sequencing. The first publicly available draft genome of date palm was assembled for Khalas variety of date palm by Al Dous et al. (2011). More than 3.5 million polymorphic sites were identified by sequencing of eight other cultivars, including females of the Deglet Noor and Medjool varieties and their backcrossed males.

Genome wide duplication has occurred in date palm and chromosomal regions has low density of single nucleotide polymorphism and most of the genes for sugar metabolism and stress resistance are found in this region (AlMssalem et al., 2013). Cultivar specific SNPs have been identified for eight date palm varieties by sequencing of mitochondrial and plastid genomes but the sequences of plastid and mitochondrial genomes were found to have low level of variation thus suggesting the use of nuclear SNPs for molecular characterization of date palm (Sabir et al., 2014). Recently genomic regions 
having geographically segregating SNPs were also identified by genotyping 65000 SNPs data from leaves and fruits of seventy female date palm cultivars from all the growing regions (Mathew et al., 2015).

\section{Conclusions and future directions}

Reproducibility, accuracy, codominance, high polymorphism and low cost are the characteristics of a good marker system. Although SSRs are commonly being used for most of the crops these days, there are some problems in their use like correct sizing of SSR bands because of the electrophoresis artefacts, unequal allele amplification by PCR and size homoplasy which means that the alleles are of equal size but they may not necessarily have the same sequence. Moreover null alleles may result if mutation occurs in the SSR primer binding site (Jones et al., 2007). Another disadvantage of SSR markers is that if some mutation occurs in the primer binding site may result in a mutant copy of gene that would be lacking normal function of that gene (Jones et al., 2007). Similarly if phylogenetic study is based on a single gene or marker such results may be deceptive because if horizontal gene transfer is involved then other genes may show different evolution rate (Patwardhan, 2014).

SSR markers are important for evaluation of taxonomy up to species level but sequence based phylogenetic analysis is needed to detect the sufficient level of variation (Pintaud et al., 2010).

Since the structure of basic biomolecules of all organisms is similar and morphological characters of an organism are the illustration of its genome, protein and transcriptome profile, the study of phylogeny based on morphological traits is as important as molecular based phylogenetic study. Thus the combination of the two methods gives strength to the phylogenetic relationship of the organism (Patwardhan et al., 2014). Hence it is concluded that PCR based molecular markers have been successfully used for the genetic diversity analysis of the date palm cultivars and in some cases identification keys have also been developed for few cultivars, but recent disclosure of the date palm genome and advances in molecular biological techniques necessitate the development of a universal key of all the date palm cultivars based on the knowledge of the date palm genome sequence.

\section{References}

Abdulla M, Gamal O. 2010. Investigation on molecular phylogeny of some date palm (Phoenix dactylifera L.) cultivars by protein, RAPD and ISSR markers in Saudi Arabia. Aust J Crop Sci 4: 23-28.

Adawy SS, Hussein EH, Ismail S, El-Itriby HA. 2005. Genomic diversity in date palm (Phoenix dactylifera L.) as revealed by AFLPs in comparison to RAPDs and ISSRs. Arab J Biotechnol 8: 99-114.

Ahmed TA, Al-Hadidi S. 2014. Molecular characterization of date palm (Phoenix dactylifera L.) using Inter Simple Sequence Repeat (ISSR) markers. In: Zaid A, Alhadrami GA. (eds). Proceedings of the Fifth International Date Palm Conference. Abu Dhabi, UAE. March 16-18. Khalifa International Date Palm Award. pp:161
Ahmed TA, Al-Qaradawi A. 2009. Molecular phylogeny of Qatari date palm genotypes using simple sequence repeats markers. Biotechnology 8: 126-131.

Akhtar W, Rasheed A, Shinwari ZK, Naqvi SMS, Mahmood T. 2014. Genetic characterization of different Pakistani date palm varieties. Pak J Bot 46: 2095-2100.

Akkak A, Scariot V, Torello Marinoni D, Boccacci P, Beltramo C, Botta R. 2009. Development and evaluation of microsatellite markers in Phoenix dactylifera L. and their transferability to other Phoenix species. Biol Plant 53(1): 164-166.

Al-Dous, EK, George B, Al-Mahmoud ME, Al-Jaber MY, Wang H, Salameh YM, Al-Azwani EK, Chaluvadi S, Pontaroli AC, DeBarry J, Arondel V, Ohlrogge J, Saie IJ, Elmeer KMS, Bennetzen JL, Krueger RR and Malek JA. 2011. De novo genome sequencing and comparative genomics of date palm (Phoenix dactylifera). Nat. Biotechnol. 29: 521-527.

Al-Faifi SA, Migdadi HM, Algamdi SS, Khan MA, Ammar MH, Al-Obeed RS, Al-Thamra MI, El-Harty EH, Jakse J. 2016. Development, characterization and use of genomic SSR markers for assessment of genetic diversity in some Saudi date palm (Phoenix dactylifera L.) cultivars. Electronic Journal of Biotechnology 21: 18-25.

Al-Khalifah NS, Askari E, Khan AS. 2012. Molecular and morphological identification of some elite varieties of date palms grown in Saudi Arabia. Emir J Food Agric 24: 456-461.

Al-Mssallem IS, Hu S, Zhang X, Lin Q, Liu W, Tan J, Yu X, Liu J, Pan L, Zhang T. 2013. Genome sequence of the date palm Phoenix dactylifera $\mathrm{L}$. Nat commun 4.

Al-Najm A, Luo S, Ahmad NM, Pourkheirandish M, Trethowan R. 2017. Molecular variability and population structure of a core collection of date palm (Phoenix dactylifera L.) cultivars from Australia and the Middle East. AJCS 11(09):1106-1115.

Al-Qurainy F, Khan S, Al-Hemaid FM, Ali MA, Tarroum M, Ashraf M. 2011. Assessing molecular signature for some potential date (Phoenix dactylifera L.) cultivars from Saudi Arabia, based on chloroplast DNA sequences rpoB and psbAtrnH. Int J Mol Sci 12(10): 6871-6880.

Al-Ruqaishi IA, Davey M, Alderson P, Mayes S. 2008. Genetic relationships and genotype tracing in date palm (Phoenix dactylifera L.) in Oman based on microsatellite markers. Plant Genet Resour 6(1): 70-72.

Arabnezhad H, Bahar M, Mohammadi HR, Latifian M. 2012. Development, characterization and use of microsatellite markers for germplasm analysis in date palm (Phoenix dactylifera L.). Sci Hort 134: 150-156

Azeqour M, Majourhat K, Baaziz M. 2002. Morphological variations and isoenzyme polymorphism of date palm clones from in vitro culture acclimatized and established on soil in South Morocco. Euphytica 123: 57-66.

Barthet MM, Hilu KW. 2007. Expression of matK: functional and evolutionary implications. Am J Bot 94: 1402-1412.

Billotte N, Marseilla N, Brottier P, Noyer JL, Jacquemoud-Collet JP, Moreau C, Couvreur T, Chevallier MH, Pintaud JC, Risterucci AM. 2004. Nuclear microsatellite markers for the date palm (Phoenix dactylifera L.): characterization, utility across the genus Phoenix and in other palm genera. Mol Ecol Notes4(2): 256-258.

Bodian A, Elhoumaizi MA, Nadir KN, Hasnoui A, Nachtigall M, Wehling P. 2012. Genetic diversity analysis of date palm (Phoenix dactylifera L.) cultivars from Figuig oasis (Morocco) using SSR markers. IJSAT 2: 96-104.

Botstein, D., R. L. White, M. Skolnick and R. W. Davis. 1980. Construction of a genetic linkage map in man using restriction fragment length polymorphisms. Am J Hum Genet 32: 314-331.

Burgess KS, Fazekas AJ, Kesanakurti PR, Graham SW, Husband BC, Newmaster SG, Percy DM, Hajibabaei M, Barrett SCH. 2011. Discriminating plant species in a local temperate flora using the rbcL+matK DNA barcode. Methods Ecol Evol 2: 333-340.

Cao BR, Chao C-CT. 2002. Identification of date cultivars in California using AFLP markers. HortScience 37: 966-968.

Chaludvadi SR, Khanam S, Aly MA, Bennetzen JL. 2014. Genetic diversity and population structure of native and introduced date palm (Phoenix dactylifera) germplasm in the United Arab Emirates. Trop Plant Biol 7: 30-41. 
Diaz S, Pire C, Ferrer J, Bonete MJ. 2003. Identification of Phoenix dactylifera $\mathrm{L}$. varieties based on amplified fragment length polymorphism (AFLP) markers. Cell Mol Biol Letters 8: 891-900.

Eissa, E, El-Razek AA, El-Sharabasy S, Rizk R. 2009. Morphological and molecular genetic characterization of soft date palm (Phoenix dactylifera $\mathbf{L}$.) cultivars in Egypt. Egypt $\mathbf{J}$ Genet Cytol 38: 269-284.

El-Assar AM, Krueger RR, Devanad PS, Chao CT. 2005. Genetic analysis of Egyptian date (Phoenix dactylifera L.) accessions using AFLP markers. Genet Resour Crop Evol 52:601-607.

Elhoumaizi MA, Devanand PS, Fang J, Chao C-CT. 2006 Confirmation of 'Medjool' date as a landrace variety through genetic analysis of 'medjool' accessions in Morocco. J Am Soc Hortic Sci 131: 403-407.

Elhoumaizi MA, Saaidi M, Oihabi A, Cilas C. 2002. Phenotypic diversity of date-palm cultivars (Phoenix dactylifera L.) from Morocco. Genet Resour Crop Evol49: 483-490.

Elmeer K, Mattat I. 2015. Genetic diversity of Qatari date palm using SSR markers. Genet Mol Res 14: 1624-1635.

Elmeer K, Sarwath H, Malek J, Baum M, Hamwieh A. 2011. New microsatellite markers for assessment of genetic diversity in date palm (Phoenix dactylifera $\mathrm{L}$.). 3Biotech. 1: 91-97.

Elshibli S, and Korpelainen H. 2010. Identity of date palm (Phoenix dactylifera L.) germplasm in Sudan: from morphology and chemical characters to molecular markers. Acta Hortic. 859: 143-153.

Elshibli S, Korpelainen H. 2009. Biodiversity of date palms (Phoenix dactylifera L.) in Sudan: chemical, morphological and DNA polymorphisms of selected cultivars. Plant Genet Resour 7: 194-203.

El-Yazal SS, Alharby H, El-Yazal MS, Hassan G, Rady M. 2017. Molecular identification of some seedling of date palm (Phoenix dactylifera L.) Males'trees. J Anim Plant Sci 27: 1287-1294.

Enan M, Ahmed A. 2014. DNA barcoding based on plastid matK and RNA polymerase for assessing the genetic identity of date (Phoenix dactylifera L.) cultivars. Genet Mol Res 13: 3527-3536.

Faqir N, Muhammad A, Shehzad A, Rahman H, Hyder MZ, Ali GM. 2016. Simple Sequence Repeat (SSR) markers show greater similarity among morphologically diverse Date palm (Phoenix dactylifera L.) cultivars grown in Pakistan. Pure and Applied Biology 5: 483-498.

Filho JAF, de Brito LS, Leão AP, Alves AA, Formighieri EF, Júnior MTS. 2017. In silico approach for characterization and comparison of repeats in the genomes of oil and date palms. Bioinform Biol Insights 11:1-12.

Gupta P, Roy J, Prasad M. 2001. Single nucleotide polymorphisms: a new paradigm for molecular marker technology and DNA polymorphism detection with emphasis on their use in plants. Curr Sci 80: 524-535.

Hahn WJ. 2002. A molecular phylogenetic study of the Palmae (Arecaceae) based on atpB, rbcL, and 18S nrDNA sequences. Syst Biol 51: 92-112.

Haider MS, Khan IA, Jaskani M, Naqvi SA, Hameed M, Azam M, Khan AA, Pintaud JC. 2015. Assessment of morphological attributes of date palm accessions of diverse agro-ecological origin. Pak J Bot 47: 1143-1151.

Hammadi H, Vendramin GG, Ali A. 2011. Microsatellite diversity among Tunisian date palm (Phoenix dactylifera L.) subpopulations. Pak J Bot 43: 1257-1264.

Hammadi H, Benabderrahim MA, Elbekkay M, Ferdaous G. Triki T, Ferchichi A. 2012. Investigation of genetic variation in Tunisian date palm (Phoenix dactylifera L.) cultivars using ISSR marker systems and their relation with fruit characteristics. Turk J Biol 36: 449-458.

Hammadi H, Mokhtar R, Mokhtar E, Ali F. 2009. New approach for the morphological identification of date palm (Phoenix dactylifera L.) cultivars from Tunisia. Pak J Bot 41: 2671-2681.

Hamwieh A, Farah J, Moussally S, Al-Sham'aa K, Almer K, Khierallah H, Udupa S, Lababidi S, Malek JA, Aaouine M, Baum M. (2010). Development of 1000 microsatellite markers across the date palm (Phoenix dactylifera 1.) Genome. Acta Hortic 882: 269-277.
Hilu KW, Black CM, Oza D. 2014. Impact of Gene Molecular Evolution on Phylogenetic Reconstruction: A Case Study in the Rosids (Superorder Rosanae, Angiosperms). PloS One 9: e99725.

Ibrahim IA, Hashem MH, Hemeida AA, Hassan MM, Maksoud A. 2014. Characterization of genetic diversity of date palm (Phoenix dactylifera L.) cultivars collected from New Valley Governorate (El-Kharga and Dakhleh) based on morphological variability and molecular markers. Life Sci J 11: 879-889.

Jahromi MK, Jafari A, Keyhani A, Mirasheh R, Mohtasebi S. 2007. Some physical properties of date fruit (cv. Lasht). Agricultural Engineering International: CIGR Journal IX. Available from :https://ecommons.cornell.edu/handle/1813/10657 [Accessed 22/4/16]

Jain SM, Al-Khayri JM, Johnson DV. 2011. Date palm Biotechnology: Springer Dordrecht Heidelberg London New York Springer Science \& Business Media. 9400713185

Jaradat AA. 2011. Biodiversity of date palm. In: Encyclopedia of Life Support Systems: Land Use, Land Cover and Soil Sciences. Oxford, UK: Eolss Publishers. p. 1-31.

Jehan T, Lakhanpaul S. 2006. Single nucleotide polymorphism (SNP)-methods and applications in plant genetics: a review. Indian J Biotechnol 5: 435-459.

Jones E, Sullivan H, Bhattramakki D, Smith J. 2007. A comparison of simple sequence repeat and single nucleotide polymorphism marker technologies for the genotypic analysis of maize (Zea mays L.). Theor Appl Genet 115: 361-371.

Jubrael JMS, Udupa SM, Baum M. 2005. Assessment of AFLPbased genetic relationships among date palm (Phoenix dactylifera L.) varieties of Iraq. J Am Soc Hortic Sci 130: 442447.

Khierallah H, Bader S, Baum M, Hamwieh A. 2011. Assessment of genetic diversity for some Iraqi date palms (Phoenix dactylifera L.) using amplified fragment length polymorphisms (AFLP) markers. Afr J Biotechnol 10: 9570-9576.

Markhand GS, Abul-Soad AA, Mirbahar AA, Kanhar NA. 2010. Fruit characterization of Pakistani dates. Pak J Bot 42:37153722.

Marsafari M, Mehrabi AA. 2013. Molecular identification and genetic diversity of Iranian date palm (Phoenix dactylifera L.) cultivars using ISSR and RAPD markers. Aust J Crop Sci 7:1160-1166.

Maryam, Jaskani MJ, Awan FS, Ahmad S, Khan IA. 2016. Development of molecular method for sex identification in date palm (Phoenix dactylifera L.) plantlets using novel sex-linked microsatellite markers. 3 Biotech 6: 22.

Mathew LS, Seidel MA, George B, Mathew S, Spannagl M, Haberer G, Torres MF, Al-Dous EK, Al-Azwani EK, Diboun I. 2015. A genome-wide survey of date palm cultivars supports two major subpopulations in Phoenix dactylifera. G3 (Bethesda) 5: $1429-1438$.

Mirbahar AA, Markhand GS, Khan S, Abul-Soad AA. 2014 Molecular characterization of some Pakistani date palm (Phoenix dactylifera L.) cultivars by RAPD markers. Pak J Bot 46: 619-625.

Mohammadi SA, Prasanna BM. 2003. Analysis of genetic diversity in crop plants: Salient statistical tools and considerations. Crop Sci 43: 1235-1248.

Naqvi SA, Khan IA, Pintaud JC, Jaskani MJ, Ali A. 2015. Morphological characterization of Pakistani Date palm (Phoenix dactylifera L.) genotypes. Pak J Agri Sci 52: 645-650.

Nickrent DL, Soltis DE. 1995. A comparison of angiosperm phylogenies from nuclear $18 \mathrm{~S}$ rDNA and rbcL sequences. Ann Mo Bot Gard: 208-234.

Nybom H, Weising K, Rotter B. 2014. DNA fingerprinting in botany: past, present, future. Investigative Genetics 5(1):1.

Odewale JO, Ataga CD, Odiowaya G, Hamza A, Agho C, Okoye MN. 2012. Multivariate analysis as a tool in the assessment of the physical properties of date Palm fruits (Phoenix dactylifera L.) in Nigeria. Plant Sciences Feed 2: 138-146.

Patwardhan A, Ray S, Roy A. 2014. Molecular Markers in Phylogenetic Studies-A Review. J Phylogen Evolution Biol 2:131. 
Pintaud J-C, Zehdi S, Couvreur T, Barrow S, Henderson S, Aberlenc-Bertossi F, Tregear J, Billotte N. 2010. Species delimitation in the genus Phoenix (Arecaceae) based on SSR markers, with emphasis on the identity of the date palm (Phoenix dactylifera L.). Seberg O, Petersen G, Barfod A, Davis $\mathrm{J}$ (Eds.): Diversity, phylogeny and evolution in the Monocotyledons. Aarhus University Press, Denmark. Pp. $267-$ 286.

Powell W, Morgante M, Andre C, Hanafey M, Vogel J, Tingey S, Rafalski A. 1996. The comparison of RFLP, RAPD, AFLP and SSR (microsatellite) markers for germplasm analysis. Mol Breed 2: 225-238.

Racchi ML, Bove A, Turchi A, Bashir G, Battaglia M, Camussi A. 2014. Genetic characterization of Libyan date palm resources by microsatellite markers. 3 Biotech. 4: 21-32.

Rani R, Kharb P, Uppal S, Dhillon S, Batra P, Chowdhury V. 2007. Genetic divergence analysis in date palm (Phoenix dactylifera L.) genotypes using RAPD markers. Haryana J Hortic Sci 36: 101-103.

Rawashdeh I, Amri A. 2006. Genetic characterization of date palm varieties using RAPD markers. Jordan J Agric Sci 2: 234-242.

Rivera D, de Castro CO, Carreno E, Inocencio C, Alcaraz F, Rios S, Palazon J, Vazquez L, Laguna E. 2008. Morphological systematics of date-palm diversity (Phoenix, Arecaceae) in Western Europe and some preliminary molecular results. Acta Hortic. 799: 97-104.

Rizk RM, El-Sharabasy SF. 2006. A descriptor for date palm (Phoenix dactylifera L.) characterization and evaluation in genebanks. Am Eurasian J Agric Environ Sci 1:133-145.

Sabir JSM, Arasappan D, Bahieldin A, Abo-Aba S, Bafeel S, Zari TA. Edris S, Shokry A, Gadalla M., Nour O. Ramadan AM. Atef A, Al-Kordy MA, El-Domyati FM. Jansen RK. 2014. Whole mitochondrial and plastid genome snp analysis of nine date palm cultivars reveals plastid heteroplasmy and close phylogenetic relationships among cultivars. PloS one 9: e94158.

Saker MM, Adawy SS, Mohamed AA, El-Itriby HA. 2006. Monitoring of cultivar identity in tissue culture-derived date palms using RAPD and AFLP analysis. Biol Plantarum 50: 198204.

Salem AOM, Rhouma S, Zehdi S, Marrakchi M, Trifi M. 2008. Morphological variability of Mauritanian date-palm (Phoenix dactylifera L.) cultivars as revealed by vegetative traits. Acta Botanica Croatica 67: 81-90.
Semagn K, Bjornstad A, Ndjiondjop M. 2006. An overview of molecular marker methods for plants. Afr J Biotechnol5(25).

Soumaya RC, Ghada B, Sonia DD, Salwa ZA, Trifi M. 2011. Molecular research on the genetic diversity of Tunisian date palm (Phoenix dactylifera L.) using the Random Amplified Microsatellite Polymorphism (RAMPO) and Amplified Fragment Length Polymorphism (AFLP) methods. Afr J Biotechnol 10: 10352-10265.

Torres RS, Uribe NO, Angulo CV, Angulo RV and Basaldúa YVH. Assessment of SSR markers used in analysis of genetic diversity of date palm (Phoenix dactylifera L.). Plant Cell Biotechnol Mol Biol 18(5\&6):269-280

Varshney RK, Graner A, Sorrells ME. 2005. Genic microsatellite markers in plants: features and applications. Trends Biotechnol 23(1), 48-55.

Yang M, Zhang X, Liu G, Yin Y, Chen K, Yun Q, Zhao D, AlMssallem IS, Yu J. 2010. The complete chloroplast genome sequence of date palm (Phoenix dactylifera L.). PloS one 5: e12762.

Yusuf A, Culham A, Aljuhani W, Ataga C, Hamza A, Odewale J, Enaberue L. 2015. Genetic diversity of Nigerian date palm (Phoenix dactylifera) germplasm based on microsatellite markers. Int J Biosci Biotechnol 7: 121132.

Zehdi S, Sakka H, Rhouma A, Salem AOM, Marrakchi M, Trifi M. 2004. Analysis of Tunisian date palm germplasm using simple sequence repeat primers. Afr J Biotechnol 3: 215-219.

Zhao Y, Williams R, Prakash CS, He G. 2012. Identification and characterization of gene-based SSR markers in date palm (Phoenix dactylifera L.). BMC Plant Biology 12(1): 237.

Zhao Y, Keremane M, Prakash CS, He G. 2017.Characterization and amplification of gene based simple sequence repeat (SSR) markers in date palm. In: AlKhayri JM, Jain SM, Johnson DV. Date palm biotechnology protocols vol II. $1^{\text {st }}$ Ed. Humana press. Pp408. ISBN: 1493971581

Zurawski G, Clegg MT. 1987. Evolution of Higher-Plant Chloroplast DNA-Encoded Genes: Implications for StructureFunction and Phylogenetic Studies. Ann Rev Plant Physiol 38: 391-418. 